\title{
Taking account of uncertainties in digital land suitability assessment
}

Brendan P Malone, Darren B Kidd, Budiman Minasny, Alex B McBratney

Simulations are used to generate plausible realisations of soil and climatic variables for input into an enterprise land suitability assessment (LSA). Subsequently we present a case study demonstrating a LSA (for hazelnuts) which takes into account the quantified uncertainties of the biophysical model input variables. This study is carried out in the Meander Valley Irrigation District, Tasmania, Australia. It is found that when comparing to a LSA that assumes inputs to be error free, there is a significant difference in the assessment of suitability. Using an approach that assumes inputs to be error free, $56 \%$ of the study area was predicted to be suitable for hazelnuts. Using the simulation approach it is revealed that there is considerable uncertainty about the 'error free' assessment, where a prediction of 'unsuitable' was made $66 \%$ of the time (on average) at each grid cell of the study area. The cause of this difference is that digital soil mapping of both soil $\mathrm{pH}$ and conductivity have a high quantified uncertainty in this study area. Despite differences between the comparative methods, taking account of the prediction uncertainties provide a realistic appraisal of enterprise suitability. It is advantageous also because suitability assessments are provided as continuous variables as opposed to discrete classifications. We would recommend for other studies that consider similar FAO (Food and Agriculture Organisation of the United Nations) land evaluation framework type suitability assessments, that parameter membership functions (as opposed to discrete threshold cutoffs) together with the simulation approach are used in concert. 
1 Taking account of uncertainties in digital land suitability assessment.

2

3 Brendan P. Malone*

4 Department of Environmental Sciences, Faculty of Agriculture and Environment, C81

5 Biomedical Building, The University of Sydney, New South Wales 2006, Australia.

6 brendan.malone@sydney.edu.au

8 Darren B. Kidd

9 Department of Primary Industries, Parks, Water and Environment Tasmania. Westbury Rd,

10 Prospect, Tasmania 7250, Australia.

11 Darren.Kidd@dpipwe.tas.gov.au

\section{Budiman Minasny}

14 Department of Environmental Sciences, Faculty of Agriculture and Environment, C81

15 Biomedical Building, The University of Sydney, New South Wales 2006, Australia.

16 budiman.minasny@sydney.edu.au

\section{Alex B. McBratney}

Department of Environmental Sciences, Faculty of Agriculture and Environment, C81

Biomedical Building, The University of Sydney, New South Wales 2006, Australia.

alex.mcbratney@sydney.edu.au

\section{*Corresponding author}




\section{Abstract}

25 Simulations are used to generate plausible realisations of soil and climatic variables for input into an enterprise land suitability assessment (LSA). Subsequently we present a case study

27 demonstrating a LSA (for hazelnuts) which takes into account the quantified uncertainties of the biophysical model input variables. This study was carried out in the Meander Valley Irrigation District, Tasmania, Australia. It is found that when compared to a LSA that assumes inputs to be error free, there is a significant difference in the assessment of suitability. Using an approach that assumes inputs to be error free, $56 \%$ of the study area was predicted to be suitable for hazelnuts. Using the simulation approach it was revealed that there is considerable uncertainty about the 'error free' assessment, where a prediction of 'unsuitable' was made $66 \%$ of the time (on average) at each grid cell of the study area. The cause of this difference is that digital soil mapping of both soil $\mathrm{pH}$ and conductivity have a high quantified uncertainty in this study area.

Despite differences between the comparative methods, taking account of the prediction uncertainties provide a realistic appraisal of enterprise suitability. It is advantageous also because suitability assessments are provided as continuous variables as opposed to discrete classifications. We would recommend for other studies that consider similar FAO (Food and Agriculture Organisation of the United Nations) land evaluation framework type suitability assessments, that parameter membership functions (as opposed to discrete threshold cutoffs) together with the simulation approach are used in concert.

\section{Introduction}

It is often stated that a useful outcome from digital soil mapping (DSM) is the ability to quantify and map prediction uncertainties. Yet, as pointed out by Grunwald (2009) in a review of DSM 
47 studies, they are often not actually quantified or mapped. Or if they are, they are not really incorporated into any further analysis. It is believed they could be invaluable for a digital soil assessment (Carre et al. 2007) project. We use them in this study specifically for digital land resource or enterprise suitability assessment.

It has been observed in recent times, an increasing activity in land resource assessments that incorporate some sort of digital soil (and sometimes climate) mapping. Recent examples include Kidd et al. (2012) in Tasmania, Australia; Harms et al. (2015) in Queensland, Australia; and van Zijl et al. (2014) in Mozambique. One reason perhaps for this activity is that one can derive with digital soil and climate modeling, very attribute specific mapping. This facilitates the opportunity for deriving quite complex suitability frameworks. These frameworks can oftentimes be specific to a particular enterprise (Kidd et al. (2012). While the suitability assessment framework design has not really progressed much more from the land evaluation guidelines prepared by the Food and Agriculture Organization of the United Nations (FAO, 1976), it is clear the suitability assessment approach is enhanced by the developments in digital soil mapping practice. An incremental advance in this area therefore is to incorporate the quantifications of uncertainty of the mapping that feed into these land or enterprise suitability assessments. It is believed that by doing this, more honest appraisals of suitability can be communicated, together with better material to use for decision making as to where efforts should be directed for improving subsequent and ongoing soil and climate mapping.

The aim of the following work is to demonstrate and evaluate one approach via a case study for incorporating input data (biophysical information) uncertainties into a land resource assessment workflow and compare with a the more traditional workflow that considers the inputs to be error free. 
Brief review of land suitability evaluation

For a contextual background we provide a brief overview of land and enterprise suitability evaluation. Rossiter (1996) and Mueller et al. (2010) have discussed the key concepts. Henceforth, we use the term land suitability assessment (LSA) as a collective term for its other connotations such as land evaluation, enterprise suitability evaluation or assessment or any such similar term that more-or-less conforms to the definition given by van Diepen et al. (1991) as "all methods to explain or predict the use potential of land". While there is a blurry concept of what 'land' is or means, we take its meaning from Triantafilis and McBratney (1993), paraphrasing from Brinkman and Smyth (1973) as "all reasonably stable, or predictably cyclic attributes of the biosphere above and below the earth surface, including those of the atmosphere, the soil and underlying geology, the hydrology, floral and faunal populations, and the result of previous human activity in which the effects significantly influence present or future land uses by man (sic)".

Soil generally features heavily in a LSA with the reason possibly traceable to the rudimentary beginnings of soil science (and pedology) and subsequent grouping and classification of soils on the basis of their productivity (Brevik and Hartemink 2010). Incorporation of climate information into LSA is also apparent. Climatic information can include variables such as temperature and precipitation (Zabel et al. 2014), to other more complexly derived variables such as frequency of frost occurrence (e.g. Kidd et al. 2012). Less common is the incorporation of socioeconomic factors (D'haeze et al. 2005). In general, greater understanding is needed in the area of coupled human and biophysical systems (Stuart et al. 2015). Intuitively, socioeconomic factors would feature heavily in a LSA because they compel activity despite biophysical 
93 constraints. Some factors include commodity price changes, institutional reforms and reforming

94 of trade practices and agreements amongst governments and organisations. However, it is not

95 altogether clear how these types of factors can be incorporated in the more common biophysical

96 centric LSAs as they are often very localized to a particular area, and difficult to track.

97 LSA projects are practiced throughout the world due principally to the need for better 98 management of natural resources which are finite - yet the pressures and demands emplaced 99 upon them are increasing — for example, through human population increase. Underlying this is 100 a fundamental need to determine whether a given site or locality would be productive or 101 unproductive for a given land use, and then secondly evaluate its biophysical status to determine 102 what the limitations are, and what the land may be best suited for. Broad global LSA programs 103 include agro-ecological zoning (Fisher and Sun, 2001) and the Fertility Capability Classification 104 (Buol et al. 1975). More recently a global high resolution LSA for a number of arable cropping 105 enterprises together with future projections was presented by Zabel et al. (2014).

106 Mueller et al. (2010) describe numerous examples of LSA programs that are nationally rolled out 107 throughout the world. There are also LSA projects that are quite locally situated. For example, 108 LSA projects have been developed in both Northern Australia (Queensland) and Tasmania 109 respectively as described in Harms et al. (2015) and Kidd et al. (2012) for enhancing agricultural 110 pursuits in those areas.

111 While LSA may have had its origins in the early development of soil science and agricultural 112 land capability classifications, the terminology and general framework were formalized with the 113 land evaluation guidelines prepared by the Food and Agriculture Organization of the United 114 Nations (FAO) in 1976 (FAO, 1976). These guidelines have strongly influenced and continue to 115 guide LSA projects throughout the world. They have also informed the development of 
116 automated LSAs via such software as ALES (Automated land Evaluation System, Rossiter 1990)

117 and MicroLEIS (De la Rosa, 2005) as examples. At its core, the FAO framework is a crop 118 specific LSA system with a 5-class ranking of suitability (FAO Land Suitability Classes) from 1:

119 Highly Suitable to 5: Permanently Not Suitable. Given a suite of biophysical information from a 120 site, each attribute is evaluated against some expert-defined thresholds for each suitability class.

121 The final evaluation of suitability for the site is the one in which is most limiting. There are a 122 number of variants to this approach such as the number of suitability classes, the weighting 123 attributed to the inputs, and also the degree of complexity of the crop specific suitability criteria.

124 This last variant is usually determined by availability of data, which is also related to spatial 125 scale at which the LSA is applied. As we have seen recently however in Zabel et al. (2014) and 126 with high resolution global soil mapping efforts such as the GlobalSoilMap project (Arrouays et 127 al. 2014), the scale issue will not be as important into the future. A further generalisation of the 128 FAO framework is evidenced by the incorporation of fuzzy threshold values for suitability 129 parameters, as opposed to discrete threshold values (Lark and Bolam 1997; Triantafilis and 130 McBratney 1993; Zabel et al. 2014). Fuzzy cut-offs are intuitively sensible because one cannot 131 easily justify (as an example) that a crop will or will not grow if a subsoil has $\mathrm{pH}$ of 5.4 as 132 opposed to 5.5, given the complexity of soil and the interactions of other soil physical and 133 chemical parameters in the system. These ideas are explored in Lark and Bolam (1997) with 134 examples.

135 Other LSA frameworks include parametric grading systems that may be multiplicative or 136 additive which ultimately rate the suitability of a land on a continuous scale rather than as 137 discrete classes. The Storie index rating (Storie, 1932) of soils is an example of a multiplicative 138 parametric LSA. A more data driven approach to the Storie Index for digital soil applications is 
139 described in O'Geen et al. (2008). An additive parametric system was developed for NSW,

140 Australia by Zhang (1989). The last LSA frameworks to be discussed are those associated with

141 crop growth and ecosystem models that estimate local productivity of specific crops given soils

142 and weather information (Mueller et al. 2010). These models are more sensitive to temporal

143 variation, which make them a more dynamic LSA approach to those discussed already. While

144 this may seem advantageous, their dynamic behavior can only be realized given appropriate

145 input information which is often difficult to obtain. Meuller et al. (2010) describes a number of

146 candidate models of this type that are applicable at different scales from global to local extents.

147 The widespread application of these models in LSA projects is limited due to their sophistication

148 and inflexibility about input data requirements as many are designed for a specific purpose and

149 applicable only to their origin.

150 Other than fuzzy classification methods (Triantafilis and McBratney 1993; Zabel et al. 2014), the 151 assumption of LSAs is that the input data and parameter thresholds are free of error. However, 152 soil is complex and can vary quite erratically in the context of space and time (Webster 2000), 153 and subsequent model-based predictions of soil phenomena are anything but 'error free' (Brown 154 and Heuvelink 2005). In noting this, Harms et al. (2015) provided additional mapping of a confidence measure (based on Mahalanobis distance calculations) of the suitability 156 classifications. They were able to state explicitly where suitability classifications were likely to 157 be good and where they were likely to be uncertain. Indeed this is helpful and a good step 158 forwards, but possibly a more direct way to derive a measure of land suitability is to incorporate 159 the measures of prediction uncertainty into the final assessment. 
162 The case study is situated in the Meander Valley, in north-east Tasmania (Figure 1). This area, 163 together with the Midlands irrigation district in central Tasmania is a focus site of the 'Wealth 164 from Water' (WfW) project that commenced in November 2010 (Kidd et al. 2012). The Meander 165 study area has diverse soils and landscapes; the eastern extremities are part of the Launceston 166 tertiary Basin (Doyle, 1993), with mainly duplex profiles (sharp change in texture between the A 167 and B horizons, and sodic subsoils (exchangeable sodium \% $>6$, Sodosols (Australian Soil 168 Clasification (ASC) Isbell 2002)); Lixisols or Solonetz (World Reference Base (WRB) (IUSS 169 Working Group 2007). Productive areas of deep, gradational Tertiary Basalt soils are formed 170 around Deloraine (Ferrosols (ASC); Nitisols or Acrisols (WRB)), and highly complex, poorly 171 drained alluvial soils to the south near Meander (Hydrosols, Kandosols, Chromosols (ASC); 172 Gleysols, Fluvisols and Lixisols (WRB) (Spanswick and Zund 1999).

173 Current land use is mainly grazing, cereal and vegetable cropping in the east, and dairying in the 174 west and south, with forestry and conservation in rocky and mountainous areas. Average annual 175 rainfall is approximately $>800 \mathrm{~mm} / \mathrm{yr}$.

176 The aim of the WfW project was to develop a LSA for a number of agricultural enterprises to 177 support irrigated agricultural expansion across the state (Kidd et al. 2012). Kidd et al. (2014) 178 describe the varied functions of this project which have included extensive soil sampling and 179 climate monitoring, together with digital soil and climate modeling to support a LSA for 20 180 listed agricultural enterprises.

$<<$ Insert Figure 1 around here $>>$

183 Figure 1. Locality map of the Meander Valley study area, Tasmania. 
185 This case study describes a LSA for hazelnuts in the Meander Valley with two contrasting

186 approaches. The first approach (Approach 1) is a LSA that considers the input variables to be

187 error free. While the second approach (Approach 2) is a LSA which takes into consideration the

188 prediction uncertainties of the input variables. The commonality between both approaches is the

189 underlying assessment — it being based on the FAO most limiting factor model of land

190 evaluation. As with all agricultural enterprises investigated for the WfW project, hazelnut

191 suitability thresholds were determined by experts from the Tasmanian Government Department

192 of Primary Industries, Parks, Water and Environment (DPIPWE), together with input from the

193 Tasmanian Institute of Agriculture as well as from research trial information, existing literature

194 and consultation with industry experts. The suitability thresholds are related to biophysical

195 information pertaining predominantly to soil and climatic information, and are tabulated in Table

196 1. Soil and climate variables were predicted using digital soil mapping methods (McBratney et

197 al. 2003). Details of the methods used for preparing and modeling the soil variable data are

198 described in Kidd et al. (2012), while the approaches used for the climate variables are described

199 in Webb et al. (2014; 2015). A short description of the modeling approaches used for each soil

200 and climate variable follows in the next section, but the main details are summarized in Table 2 ,

201 together with the model validation diagnostics of both the predictions and quantifications of

202 uncertainty.

203

$204<<$ Insert Table 1 around here $>>$

205 Table 1. Suitability parameters and thresholds for hazelnuts. Sourced from DPIPWE (2015).

206

207

Digital soil and climate modeling for land suitability assessment 
208 An extensive soil sampling and climate modeling program was established in the Meander 209 Valley in 2010 (Kidd et al. 2012; Kidd et al. 2015). In total 576 soil cores were extracted from 210 various locations throughout the area and analysed for a number of physical and chemical soil 211 properties both in the laboratory and with chemometric techniques dependent on mid-infrared 212 soil spectral calibrations (Kidd et al. 2015). Climate and temperature monitoring throughout the 213 Meander was carried out over 2010 and 2011 using a network of distributed temperature sensors 214 (Webb et al. 2014), and calibrated to long-term climate data (Webb et al 2015). Rainfall 215 information was sourced from Australian Bureau of Meteorology monitoring sites located within 216 and surrounding the study area (Webb et al. 2014). Soil sampling and climate monitoring 217 network were conducted and installed respectively by field officers of the Tasmanian 218 Government. For many sites that were situated on public or Government administered land, no 219 permission was required for sampling or installation of temperature sensors. For sites that were 220 situated on private landholdings, Government officers sought permission for access. In the rare 221 situation where permission was not granted, the sampling or monitoring site was moved to an 222 alternative and agreeable location.

223 The common workflow for all digital soil and climate variable mapping entailed:

224 1. The randomized splitting of observational data into calibration and validation datasets. 225 Here a $75 \%$ and $25 \%$ split was used respectively for calibration and validation datasets. 226 For consistency, the same calibration and validation datasets (soil, climate, rainfall) were used for all target variables, before removal of missing values.

2. Environmental covariates were sourced from DPIPWE and other government repositories which included derivatives from a digital elevation model (STRM DEM (Gallant et al 230 2011), gamma radiometric information (Minty et al. 2009), and spectral indices derived 
from Landsat 7 ETM+ satellite. Soil modeling involved using principal components of all sourced covariates, while principal components of the digital elevation model derivatives (only) were used for the climate variables (Webb et al. 2015).

3. Modeling of continuous variables was based on a regression kriging framework that entailed Cubist regression tree modeling (Quinlan 1992) followed by model residual modeling (with variograms) and kriging. Spherical or exponential models were considered only. Visual criteria of the global variogram of residuals were used to determine whether regression kriging should be pursued or not. Otherwise regression modeling was used only. Categorical variable modeling entailed either the fitting of binomial or ordinal logistic models, dependent on the nature of the target variable information.

4. Prediction uncertainties for continuous variables were quantified using an empirical approach as described in Malone et al. (2014) where the model errors within each partition of a Cubist model were used to form geographically specific error distributions (via leave-one-out cross validation) in order to estimate $90 \%$ prediction intervals. For categorical variables, the prediction probabilities were used as measures of uncertainty.

5. Validation statistics for continuous variables included the root mean square error (RMSE) and Lin's concordance correlation coefficient (CCC; Lin 1989). The prediction interval coverage probability (PICP, Solomatine and Shrestha 2006) was used to evaluate the efficacy of the $90 \%$ prediction intervals. The PICP is the proportion of actual observations that are encapsulated by their prediction interval, and ideally will be equivalent the level of confidence associated with the prediction interval. For categorical variables, overall accuracy and kappa statistic (Congalton 1991) were used. Validation 

for the validation data set only.

256

257

$<<$ Insert Table 2 around here $>>$

258

Table 2. Metadata and model diagnostics of digital soil and climate mapping relevant to LSA for 259 hazelnuts.

261 All maps of the biophysical properties (together with uncertainties) used for the hazelnut LSA are supplied as supplementary material (supplementary material 1) to this research. Some details specific to each modeling variable are as follows.

Soil Depth

Soil depth was modeled in a two-step procedure. The first step was binomial modeling of whether soil depth greater than $1.5 \mathrm{~m}$ or not. The rationale behind this was that soil coring was done to a maximum of $1.5 \mathrm{~m}$ depth, or depth-to-lithic contact, whichever was first. The second step involved regression kriging modeling of soil depth where soil depth was less than $1.5 \mathrm{~m}$. The outputs from both steps were used for the LSA, which is discussed further on. The two-step modeling procedure described in this study has been used previously by Gastaldi et al. (2012) for mapping the occurrence and thickness of soil horizons. In that study, the first step involved modeling the occurrence of horizon classes, while the second step involved modeling 274 the depth of the soil horizons. 
277 A mass-preserving soil depth spline (Bishop et al. 1999) was used to harmonise observed soil

278 profile data in order to impute data for the $0-15 \mathrm{~cm}$ depth intervals for all locations. Spatial

279 modeling was performed using regression kriging framework.

280 Soil Drainage

281 Digital soil mapping of soil drainage was carried out as in the method described by Kidd et al.

282 (2014). Essentially this method codifies the descriptive soil drainage classification as detailed in

283 National Committee on Soil and Terrain (2009) into an ordinal value. The numerical classes

284 were then spatially modeled as a continuous variable using regression kriging.

\section{Stoniness}

287 Soil stoniness or percentage of coarse fragments greater than $2 \mathrm{~mm}$ was modeled in a two-step 288 procedure, much for the same reasons as for soil depth. Here the first step was a binomial logistic 289 regression model which considered the presence vs. absence of coarse fragments. The second 290 step entailed an ordinal logistic regression of the coarse fragment incremental percentage classes 291 (6) as described in National Committee on Soil and Terrain (2009).

\section{Incidence of Frost}

294 The method for estimating the probability of frost incidence at each location is described in 295 Webb et al. (2014; 2015). Spatial modeling occurred as a two-step procedure because many sites had no incidence of frost occurrence. Subsequently the first step entailed a binomial logistic regression of presence vs. absence of frost occurrence followed by the second step of regression 
Temperature, rainfall and chill hour requirements.

302 These were all spatially modeled as continuous variables. A multiple linear regression model was

303 used for rainfall modeling, due to the small number of rainfall observations. The validation

304 statistics reported are from a leave-one-out-cross validation. The PICP for the validation of 305 prediction uncertainties is based on the calibration data. Cubist regression models were used for 306 temperature and chill hours, with residual kriging being appropriate for chill hours only.

Approach 1. Land suitability assessment without considering prediction uncertainties

Raster maps of each of the hazelnut LSA variables were interrogated pixel-by-pixel from which an assessment of suitability was derived using the most limiting factor approach. For variables

311 that were modeled as a two-step procedure (soil depth, stoniness, frost incidence), a positive 312 condition invoked the interrogation of the map from second part of the two-step procedure. 313 Using the soil depth variable as an example, if a pixel on the prediction map recorded a positive 314 score (likely presence that depth to lithic contact is less than $1.5 \mathrm{~m}$ ) contact, the second map was 315 interrogated to estimate the depth to the lithic contact.

317 Approach 2. Land suitability assessment in consideration of prediction uncertainties.

318 The basis of the approach is a simulation of possible realisations (pixel-by-pixel) of the input 319 variables before assessing the suitability using the most limiting factor approach. For the continuous variables the prediction intervals were sampled with an assumption of normal

321 distribution upon each realisation. For the categorical variables, sampling from either the

322 binomial or multinomial distributions of the prediction probabilities was performed. In 
323 consideration of variables subject to the two-step model procedure, the second condition was

324 invoked where a presence or occurrence of the phenomenon in question was found for a given

325 sample. If the condition was invoked, the probability distribution of the second variable was

326 sampled.

327 There were two issues to consider in this approach. The first was an issue of computation where

328 compared to approach 1 , the computation time can increase dramatically with increasing number

329 of realisations. Besides using multi-core compute facilities, Latin Hypercube Sampling (LHS)

330 was used to sample from the multivariate distributions of the continuous variables. LHS

331 sampling is a more efficient sampling approach to random sampling if the objective is to ensure

332 the multivariate distributions are sampled entirely (Pebesma and Heuvelink 1999).

333 The second issue was one of rationality in terms of the multivariate information generated from

334 each realisation. The rationality here was the maintenance of correlations between the LSA

335 variables. Subsequently a modified LHS was used where the correlation matrix of the sample is

336 corrected to match that of the data that is being sampled. The correction was made through the

337 use of the Huntington-Lyrintzis algorithm (Huntington and Lyrintzis 1998). Implementation of

338 correlation matrix corrected LHS was performed using of the LHScorcorr function in the pse R

339 package (Chalom and Prado 2014).

340 In this study 100 realisations were made in order to estimate probabilities of each suitability class

341 at each map pixel. The probabilities were estimated as the number of occurrences of each

342 suitability class divided by the total number of realisations. Further analysis of these outputs is

343 presented in the results.

345 Software. 
346 The entire workflow of this study was implemented in the R scripting language (R Core Team

347 2015) except for the creation of map products which were created using ArcGIS (ESRI Inc.).

348 Specifically, custom functions were built for the hazelnut LSA. The raster (Hijams 2015)

349 package with associated rgdal (Bivand et al. 2015) and sp (Bivand et al. 2013) packages were

350 used for handling and manipulating all GIS processes. Cubist models were implemented from the

351 Cubist (Kuhn et al. 2014) package and the multinomial and ordinal logistic modeling were

352 carried out using the nnet and MASS packages respectively (Venables and Ripley, 2002).

353 Variogram modeling entailed the usage of geostatistical functions from gstat (Pebesma 2004).

354 Many of the processes, including applying models spatially and applying the LSA in the

355 presence of prediction uncertainties were distributed across multiple compute nodes (8) to

356 improve the computation efficiency. This was done using specialist $\mathrm{R}$ packages parallel (R Core

357 Team 2015) and doParallel (Revolution Analytics and Weston 2014).

\section{Results}

360 The suitability map for hazelnuts calculated without considering uncertainty is shown in Figure

361 2. This map indicates that approximately $6 \%$ of the study area has the biophysical characteristics

362 that are well suited for hazelnuts. 56\% was classified as suitable, while $20 \%$ and $18 \%$ 363 respectively were classified as marginally suited and unsuited. The classification of 'unsuited' 364 within the area was predominantly on the basis of soil $\mathrm{pH}$. Those areas where unsuited is 365 classified have a predicted low topsoil $\mathrm{pH}(<5.5)$. The areas where marginal suitability was 366 classified occur where the incidence of frost is reasonably common i.e. there is between $40-60 \%$ 367 likelihood that there will be no days in June, July or August (Southern Hemisphere Winter) 368 where temperature reaches $-6^{\circ} \mathrm{C}$. From this analysis, there were very few situations where there 
369 were multi-factor issues causing limitations. One exception however was in the northern 370 peninsula area where both soil $\mathrm{pH}$ and frost limitations were predicted. Maps showing the

371 limitation classifications for each soil and climate LSA parameter are to be found in the 372 supplementary material (supplementary material 2) of this research manuscript.

$374<<$ Insert Figure 2 around here $>>$

375 Figure 2. Hazelnut suitability classification assuming LSA inputs are error free.

376

377 The main outputs from approach 2 are the four maps shown in Figure 3. This shows the 378 probability maps for each suitability class: 3a) well suited, 3b) suited, 3c) marginally suited and $3793 \mathrm{~d}$ ) unsuited. The mean probability for each suitability class (in the same sequential order as 380 before) is $6 \%, 21 \%, 7 \%$, and $66 \%$ respectively. From this result, taking into consideration the 381 prediction uncertainties of the LSA parameters changes the overall assessment that was made 382 using approach 1 . The principle reason for a high likelihood of an unsuitable classification from 383 approach 2 is because of the magnitude of the input data uncertainties (which are not taken into 384 account in approach 1), and how they are propagated through the LSA.

$386<<$ Insert Figure 3 around here $>>$

387 Figure 3. Hazelnut suitability class probabilities a) Well suited, b) suited, c) marginally suited, d) 388 unsuited. 
391 Figure 4 shows maps of the probabilities to which each LSA parameter contributes to an

392 'unsuitable' assessment for hazelnut suitability. For illustrative purposes, a probability threshold 393 of 0.6 was used to delineate from Figure 3d, areas where it is reasonably certain that hazelnut 394 suitability is low. It is clear from Figure 4 that the main contributors are soil $\mathrm{pH}$ (4f) and soil 395 conductivity (4d). Soil texture (4b) and rainfall (4g) impart a minor contribution to the unfavorable suitability estimate. Figure 5 shows the comparison between approach 1 and 397 approach 2 in terms of the contribution of soil conductivity (5a and 5c) and soil $\mathrm{pH}(5 \mathrm{~b}$ and $5 \mathrm{~d})$ to the suitability estimates. Figures $5 \mathrm{c}$ and $5 \mathrm{~d}$ are the same as in Figure $4 \mathrm{~d}$ and $4 \mathrm{f}$ respectively. From approach 1, soil conductivity imparts no limitation, but from approach 2 it clearly is a main contributor. The reason for this is simple: the spatial prediction of soil conductivity is currently highly uncertain. The RMSE of the soil conductivity map was $0.12 \mathrm{dS} / \mathrm{m}$, while the threshold to 402 delineate between well suited and unsuited was $0.15 \mathrm{dS} / \mathrm{m}$. Subsequently, a large number of 403 realisations using approach 2 would sample values above this threshold. This is similarly the 404 case for soil $\mathrm{pH}$, but to a lesser degree. Here the RMSE of the soil $\mathrm{pH}$ map was 0.44 , and coupled with relatively narrow threshold criteria for suitability classification, there is going to be a relatively high likelihood that it will contribute unfavorably to suitability estimates. Despite the magnitude of uncertainty, areas where soil $\mathrm{pH}$ is a limitation on Figure $5 \mathrm{~b}$ are also observable from Figure $5 \mathrm{~d}$. The difference is that the spatial extent of soil $\mathrm{pH}$ limitation in Figure $5 \mathrm{~b}$ is less 409 constrained than in Figure 5d.

410

411

$<<$ Insert Figure 4 around here $>>$ 
412 Figure 4. Probabilities of each soil and climate variable causing hazelnuts to be unsuitable for

413 establishment, a) chill hours, b) clay content, c) soil drainage, d) soil conductivity, e) frost

414 occurrence, f) soil $\mathrm{pH}, \mathrm{g}$ ) rainfall, h) soil depth, i) temperature, $\mathrm{j}$ ) rock fragments.

415

$416<<$ Insert Figure 5 around here $>>$

417 Figure 5. Contribution of soil conductivity and $\mathrm{pH}$ to assessment of unsuitability for hazelnuts a)

418 and b) assuming inputs are error free, c) and d) taking account of the associated prediction 419 uncertainties.

420

421 As with approach 1, there was not a widespread incidence of multifactor issues from approach 2. 422 Figure 6 illustrates this which shows the probability of situations where more than one LSA 423 parameter contributes to an unfavorable suitability prediction. Mostly where the probability is 424 high, it is soil $\mathrm{pH}$ and conductivity that are the main contributing factors. Some areas in the 425 middle of the study area (to the southern edge), soil texture is also a contributing factor, together 426 with $\mathrm{pH}$ and conductivity.

427

$428<<$ Insert Figure 6 around here $>>$

429 Figure 6. Probability of multiple factors that contribute towards unsuitability for hazelnut 430 establishment.

\section{General discussion}


433 This research has been a case study to explore an enterprise LSA given uncertain input variables.

434 Taking into account the biophysical variable prediction uncertainties is a slight sophistication to 435 many LSA analyses which mainly consider inputs to be error free. One caveat to this is that the 436 workflow becomes more computationally demanding — due to the requirement to run multiple 437 realisations - and creates a significant number of items which need to be managed accordingly. 438 For example the spatial modeling and uncertainty quantification of LSA inputs requires a 439 significant amount of effort and organisation. Some of this workflow can be made more efficient 440 however through parallel and high performance computing abilities which are becoming more 441 prolific in scientific studies today.

442 It has been demonstrated (using the LSA for hazelnuts) that the prediction uncertainties of inputs 443 can significantly alter the LSA outlook compared to the situation where they are not considered 444 (approach 1). In this study, optimistic results from approach 1 were counter-matched with less 445 favorable outcomes for approach 2, despite the same information being used. As stated in Harms 446 et al. (2015), by explicitly quantifying the uncertainty of the LSA inputs, an ability to assess the 447 quality of suitability assessments can be realized. This is important for strategic decision making 448 regarding land resource management. Consequently this research highlights the importance of soils (Bouma and McBratney 2013) — in this situation for a LSA - yet it has been made

450 apparent that more needs to be done to improve the predictive grasp of soil spatial predictive 451 functions that will act as inputs for associated biophysical models. It has been considered before 452 that some ways of doing this include additional soil sampling and discovery of more informative 453 predictive covariates (Malone et al. 2014). This may well be true for most cases, and as Thomas et al. (2014) point out, digital soil mapping is a dynamic exercise, where a prediction model (and map) is never final. With new information, new calibrations and updates can be made (Kempen 
456 et al. 2015) with the long view that upon each iteration, one gets a better and more sure grasp of

457 the phenomenon being modeled.

458 The LSA for hazelnuts in this study using approach 2 serve a purpose and use despite the known

459 issue of some uncertain inputs. It was established that in consideration of the other LSA variables

460 besides soil $\mathrm{pH}$ and conductivity, there do not appear to be any major limitations for hazelnuts. A

461 pragmatic solution for a landholder to gain utility from the suitability mapping would be to

462 conduct further testing of these soil attributes if they are believed to be an issue. Relative to other

463 soil attributes the cost of measuring soil $\mathrm{pH}$ and conductivity is minimal.

464 Despite the need to make improvements in both digital soil and climate modeling, this study has

465 perhaps illustrated the limitations of using discrete thresholds for LSA parameter suitability

466 criteria. With the example used in this study, the multiple realisations do not consider or adjust

467 for those values that are near and just slightly breach the criteria that would give an unfavorable

468 suitability outcome. The severity of the limitation in terms of management potential needs

469 considering. For example, soil $\mathrm{pH}$, if close to a threshold, can easily be managed by the

470 application of lime. Whereas a limitation such as frost would be harder to manage. An approach

471 such as parametric weighting could provide a more realistic suitability framework. Furthermore,

472 while there is no disputing the expertise of the practitioners who develop biophysical parameter

473 thresholds, another (intuitive) approach is to develop membership functions rather than

474 discretized functions of the parameters thresholds when designing an enterprise LSA (Zhang et

475 al. 2015). This would effectively incorporate the uncertainty in defining what the threshold

476 values might be. This approach will in turn, circumvent those situations of borderline

477 classification that clearly can have misleading outcomes on the overall suitability assessment. As

478 was previously established, membership functions for LSA are not unheard of, with the recent 
479 study by Zabel et al. (2014) being one such example. Ultimately, due consideration of this

480 additional source of uncertainty (threshold uncertainty) would make a modest improvement upon

481 the continuous suitability assessments made in this study, despite the uncertainties of the LSA

482 inputs.

483

484 Conclusions

485 - Taking account of the uncertainties adds to the overall LSA because one can actually 486 assess the reliability of the assessment.

487

- Because the input variables are generated through a digital soil mapping approach, there is an ability to continually update the mapping as a means to improve accuracy, which will in turn, yield a more reliable LSA.

- Consideration of the biophysical variable uncertainties can have a significantly different

- Truly incorporating uncertainties into an LSA would also include the incorporation of membership functions rather than discrete thresholds for each of the biophysical input variables.

- While there are many variants of a LSA, they are fundamentally quite similar. Therefore we would suggest they could all be adapted for simulation studies as shown in this study 
502

503

504

505

506

507

508

509

510

511

512

513

514

515

516

517

518

519

520

521

522

523

524

\section{References}

Arrouays, D., McKenzie, N., Hempel, J., Richer de Forges, A., McBratney, A.B., (2014)

GlobalSoilMap: Basis of the global spatial soil information system. CRC Press, Boca Raton.

Bivand, R., Keitt, T., Rowlingson, B. (2015) rgdal: Bindings for the Geospatial Data Abstraction Library. R package version 0.9-2. . http://CRAN.R-project.org/package=rgdal.

Bivand, R., Pebesma, E., Gomez-Rubio, V. (2013) Applied spatial data analysis with R. Springer, New York.

Bouma, J., McBratney, A.B. (2013) Framing soil as an actor when dealing with wicked environmental problems. Geoderma 200-201, 130-139.

Brevik, E.C., Hartemink, A.E. (2010) Early soil knowledge and the birth and development of soil science. Catena 83, 23-33.

Brinkman, R., Smyth, A.J. (1973) Land Evaluation for Rural Purposes. Publication 17. International Institute for Land Reclamation and Improvement, Wageningen.

Brown, J.D., Heuvelink, G.B.M. (2005) Assessing uncertainty propagation through physically based models of soil water flow solute transport, in: Anderson, M. (Ed.), Encyclopaedia of Hydrological Sciences. John Wiley and Sons, Chichester. 
525 Buol, S.W., Sanchez, P.A., Cate, R.B., Granger, M., (1975) Soil fertility capability classification:

526 a technical soil classification system for fertility management, in: Bornemisza, E., Alvarado, A.

527 (Eds.), Soil Management in Tropical America. North Carolina State University, Raleigh, NC, pp.

528 126-145.

529

530 Carre, F., McBratney, A.B., Mayr, T., Montanarella, L. (2007) Digital soil assessments: Beyond 531 DSM. Geoderma 142, 69-79.

532

533 Chalom, A., Prado, P. (2014) pse: Parameter space exploration with Latin Hypercubes. R 534 package version 0.4.0. http://CRAN.R-project.org/package=pse.

536 Congalton, R.G. (1991) A review of assessing the accuracy of classifications of remotely sensed 537 data. Remote Sensing of Environment 37, 35-46.

538

539 De la Rosa, D., Anaya-Romero, M., Diaz-Pereira, E., Heredia, N., Shahbazi, F. (2009) Soil540 specific agro-ecological strategies for sustainable land use - A case study by using MicroLEIS 541 DSS in Sevilla Province (Spain). Land Use Policy 26, 1055-1065.

Doyle, R. (1993) Soils of the South Esk Sheet, Tasmania (southern half). Department of Primary 544 Industry and Fisheries

545

546 D'Haeze, D., Deckers, J., Raes, D., Phong, T.A., Loi, H.V. (2005) Environmental and socio547 economic impacts of institutional reforms on the agricultural sector of Vietnam Land suitability 
548 assessment for Robusta coffee in the Dak Gan region. Agriculture Ecosystems \& Environment $549 \quad 105,59-76$.

550

551 DPIPWE, (2015). Enterprise Suitability Toolkit [online] dpipwe.tas.gov.au. Available at: 552 http://dpipwe.tas.gov.au/agriculture/investing-in-irrigation/enterprise-suitability-toolkit 553 [Accessed 1 Sept. 2015].

554

FAO (1976) A Framework for Land Evaluation. Soils Bulletin 32. Food and Agriculture Organisation of the United Nations, Rome.

Fischer, G., Sun, L.X. (2001) Model based analysis of future land-use development in China. Agriculture Ecosystems \& Environment 85, 163-176.

560

561 Gallant, J., Dowling, T.I., Read, A., Wilson, N., Tickle, P., (2011). 1 second SRTM Derived 562 Digital Elevation Models User Guide. Geoscience Australia, Canberra, pp 106.

Gastaldi, G., Minasny, B., McBratney, A.B., (2012) Mapping the occurrence and thickness of 565 soil horizons within soil profiles. In: Minasny, B., Malone, B.P., McBratney, A.B. (Eds.), Digital 566 Soil Assessments and Beyond. CRC Press, Boca Raton, pp. 145-149.

567

Grunwald, S. (2009) Multi-criteria characterization of recent digital soil mapping and modeling 569 approaches. Geoderma 152, 195-207. 
571 Harms, B., Brough, D., Philip, S., Bartley, R., Thomas, M., Willis, R., Gregory, L. (2015) Digital

572 soil assessment for regional agricultural land evaluation. Global Food Security 5, 25-36.

573

574 Hijmans, R.J. (2015) raster: Geographic Data Analysis and Modeling. R package version 2.3-40.

575 http://CRAN.R-project.org/package=raster.

576

577 Huntington, D.E., Lyrintzis, C.S. (1998) Improvements to and limitations of Latin hypercube 578 sampling. Probabilistic Engineering Mechanics 13, 245-253.

579

580

581

Isbell, R., (2002) The Australian Soil Classification - Revised Edition, Australian Soil and Land Survey Handbooks Series 4. CSIRO PUBLISHING, Australia.

582

583

584

IUSS Working Group WRB, 2007. World reference base for soil resources 2006. First update 2007. World Soil Resources Report No. 103. (FAO: Rome)

585

586

Kempen, B., Brus, D.J., de Vries, F. (2015) Operationalizing digital soil mapping for nationwide 587 updating of the 1:50000 soil map of the Netherlands. Geoderma 241, 313-329.

588

589

Kidd, D.B., Malone, B.P., McBratney, A.B., Minasny, B., Webb, M.A. (2014) Digital mapping 590 of a soil drainage index for irrigated enterprise suitability in Tasmania, Australia. Soil Research 591 $52,107-119$.

592 
593 Kidd, D.B., Webb, M.A., Grose, C.J., Moreton, R.M., Malone, B.P., McBratney, A.B., Minasny,

B. (2014) Operational digital soil assessment for enterprise suitability in Tasmania, Australia.

595

596 Kidd, D.B., Webb, M.A., Grose, C.J., Moreton, R.M., P, M.B., McBratney, A.B., Minasny, B.,

597 Viscarra-Rossel, R.A., Sparrow, L.A., Smith, R., (2012) Digital soil assessment: Guiding 598 irrigation expansion in Tasmania, Australia, in: Minasny, B., Malone, B.P., McBratney, A.B. 599 (Eds.), Digital Soil Assessments and Beyond. CRC Press, Boca Raton, pp. 3-9.

600

601 Kuhn, M., Weston, S., Keefer, C., Coulter, N. (2014) C code for Cubist by Ross Quinlan (2014).

602 Cubist: Rule- and Instance-Based Regression Modeling. $\mathrm{R}$ package version 0.0.18. 603 http://CRAN.R-project.org/package=Cubist.

604

605

Lark, R.M., Bolam, H.C. (1997) Uncertainty in prediction and interpretation of spatially variable 606 data on soils. Geoderma 77, 263-282.

607

608 Lin, L.I. (1989) A concordance correlation coefficient to evaluate reproducibility. Biometrics 45, $609 \quad 255-268$.

610

611 Malone, B.P., Minasny, B., Odgers, N.P., McBratney, A.B. (2014) Using model averaging to 612 combine soil property rasters from legacy soil maps and from point data. Geoderma 232, 34-44. 613

614 McBratney, A.B., Mendonca Santos, M.L., Minasny, B. (2003) On digital soil mapping. 615 Goderma 117, 3-52. 
617 Minty, B., Franklin, R., Milligan, P., Richardson, L.M., Wilford, J., (2009) New radiometric map 618 of Australia. Exploration Geophysics 40(4), 325-333.

619

620 Mueller, L., Schindler, U., Mirschel, W., Graham-Shepherd, T., Ball, B.C., Helming, K., 621 Rogasik, J., Eulenstein, F., Wiggering, H. (2010) Assessing the productivity function of soils. A 622 review. Agronomy for Sustainable Development 30, 601-614.

623

624 O'Geen, A.T., Southard, S.B., Southard, R.J. (2008) A revised Storie Index for use with digital 625 soils information. ANR Publication 8335. ANR University of California, Davis, California.

626

627 Pebesma, E. (2004) Multivariable geostatistics in S: the gstat package. Computers \& 628 Geosciences 30, 683-691.

629

630 Pebesma, E.J., Heuvelink, G.B.M. (1999) Latin hypercube sampling of Gaussian random fields.

631 Technometrics 41, 303-312.

632

633 Quinlan, R., (1992) Learning with continuous classes, Proceedings of the 5th Australian Joint 634 Conference On Artificial Intelligence, Hobart, Tasmania, pp. 343-348.

635

636 R Core Team (2015) R: A language and environment for statistical computing. R Foundation for 637 Statistical Computing. Vienna, Austria, http://www.R-project.org/. 
639 Revolution Analytics., Weston, S. (2014) doParallel: Foreach parallel adaptor for the parallel 640 package. R package version 1.0.8. http://CRAN.R-project.org/package=doParallel.

641

642 Rossiter, D.G. (1990) ALES - A framework for land evaluation using a microcomputer. Soil Use 643 and Management 6, 7-20.

644

645 Rossiter, D.G. (1996) A theoretical framework for land evaluation. Geoderma 72, 165-190.

646

647 Shrestha, D.L., Solomatine, D.P. (2006) Machine learning approaches for estimation of 648 prediction interval for the model output. Neural Networks 19, 225-235.

649

650

Spanswick, S., Zund, P. (1999) Quamby Soil Report - Reconnaissance Soil Map Series of 651 Tasmania. A Revised Edition., Department of Primary Industries, Parks, Water and the 652 Environment., Tasmania, Australia.

653

654

Storie, R. (1932) An index for rating the agricultural value of soils. Bulletin 556. California 655 Agricultural Experiment Station, Berkeley.

656

657 Stuart, D., Basso, B., Marquart-Pyatt, S., Reimer, A., Robertson, G.P., Zhao, J. (2015) The Need 658 for a Coupled Human and Natural Systems Understanding of Agricultural Nitrogen Loss.

659 Bioscience 65, 571-578.

660 
661 The National Committee on Soil and Terrain. (2009) Australian Soil and Land Survey Field 662 Handbook. CSIRO Publishing, Collingwood, VIC.

663

664 Thomas, M., Clifford, D., Bartley, R., Philip, S., Brough, D., Gregory, L., Willis, R., Glover, M. 665 (2015) Putting regional digital soil mapping into practice in Tropical Northern Australia. 666 Geoderma 241-242, 145-157.

667

668 Triantafilis, J., McBratney, A.B. (1993) Divisional Report: Application of continuous methods of 669 soil classification and land suitability in the Lower Namoi Valley. CSIRO Divsion of Soils, 670 Canberra.

671

672

van Diepen, C.A., van Keulen, H., Wolf, J., Berkhout, J.A.A., (1991) Land evaluation: from 673 intuition to quantification, in: Stewart, B.A. (Ed.), Advances in Soil Science. Springer, New 674 York, pp. 139-204.

675

676

van Zijl, G.M., Bouwer, D., van Tol, J.J., le Roux, P.A.L. (2014) Functional digital soil mapping:

A case study from Namarroi, Mozambique. Geoderma 219, 155-161.

678

679

Venables, W.N., Ripley, B.D. (2002) Modern Applied Statistics with S. Fourth Edition. Springer, 680 New York.

681

682 Webb, M.A., Kidd, D.B., Grose, C.J., Moreton, R.M., Malone, B.P., McBratney, A.B., Minasny, 683 B., (2014) Integrating climate into the Digital Soil Assessment framework to assess land 
684 suitability, in: Arrouays, D., McKenzie, N., Hempel, J., de Forges, A.C.R., McBratney, A.

685 (Eds.), Globalsoilmap: Basis of the Global Spatial Soil Information System. CRC Press, London, 686 pp. 393-399.

687

688 Webb, M., Hall, A., Kidd, D., Minasny, B. (2015) Local-scale spatial modeling for interpolating 689 climatic temperature variables to predict agricultural plant suitability. Theor Appl Climatol, 1-21. 690

691 Webster, R. (2000) Is soil variation random? Geoderma 97, 149-163.

692

693 Zabel, F., Putzenlechner, B., Mauser, W. (2014) Global Agricultural Land Resources - A High 694 Resolution Suitability Evaluation and Its Perspectives until 2100 under Climate Change 695 Conditions. PLOS One 9.

696

697 Zhang, J., Su, Y., Wu, J., Liang, H. (2015) GIS based land suitability assessment for tobacco 698 production using AHP and fuzzy set in Shandong province of China. Computers and Electronics 699 in Agriculture 114, 202-211.

701 Zhang, L.A. (1989) A Land Suitability Evaluation System for Specific Rural Purposes in New 702 South Wales Unpublished PhD Thesis, The University of Sydney. 
1

Study area map

Figure 1. Locality map of the Meander Valley study area, Tasmania.

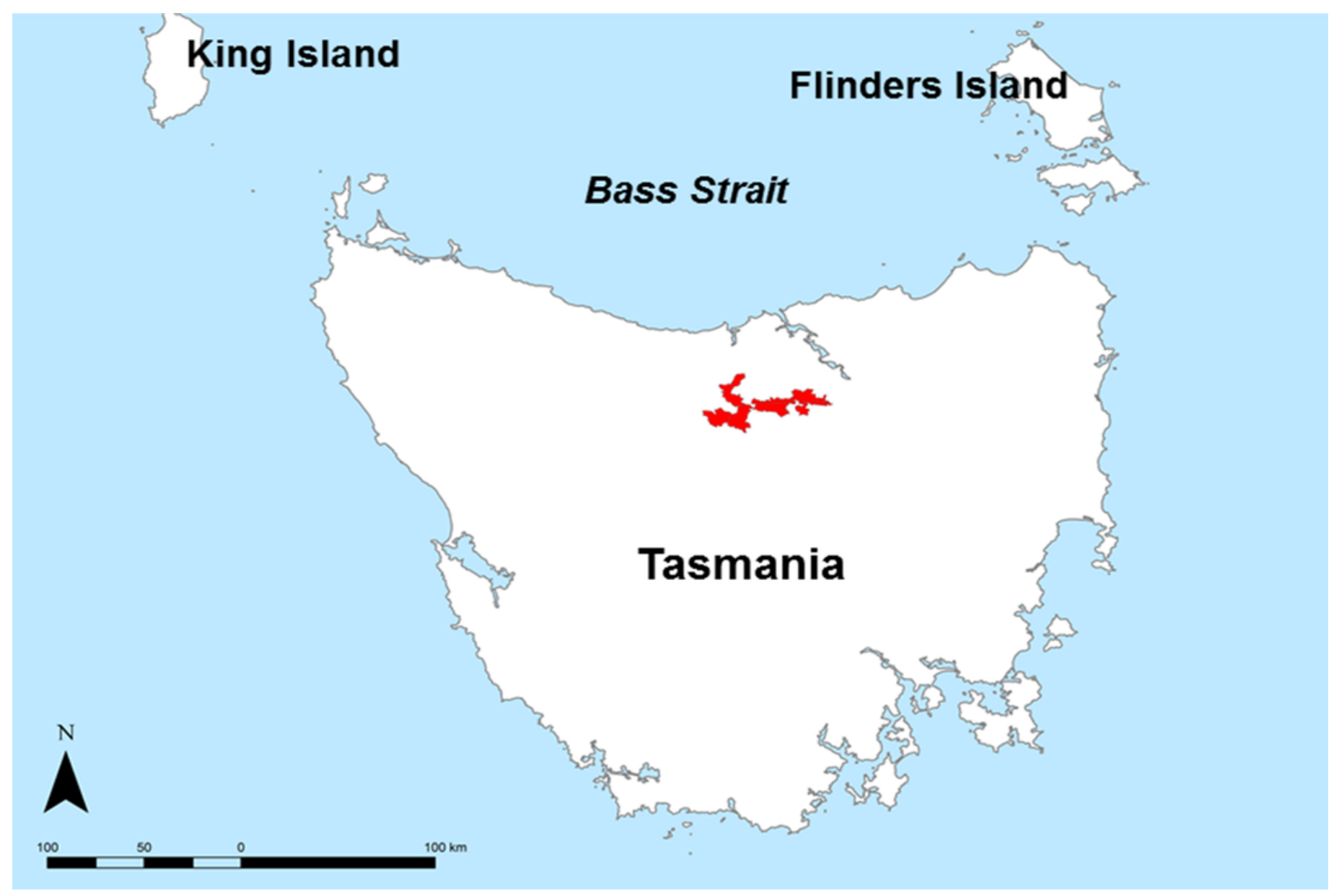




\section{2}

Error free suitability classification

Figure 2. Hazelnut suitability classification assuming LSA inputs are error free.

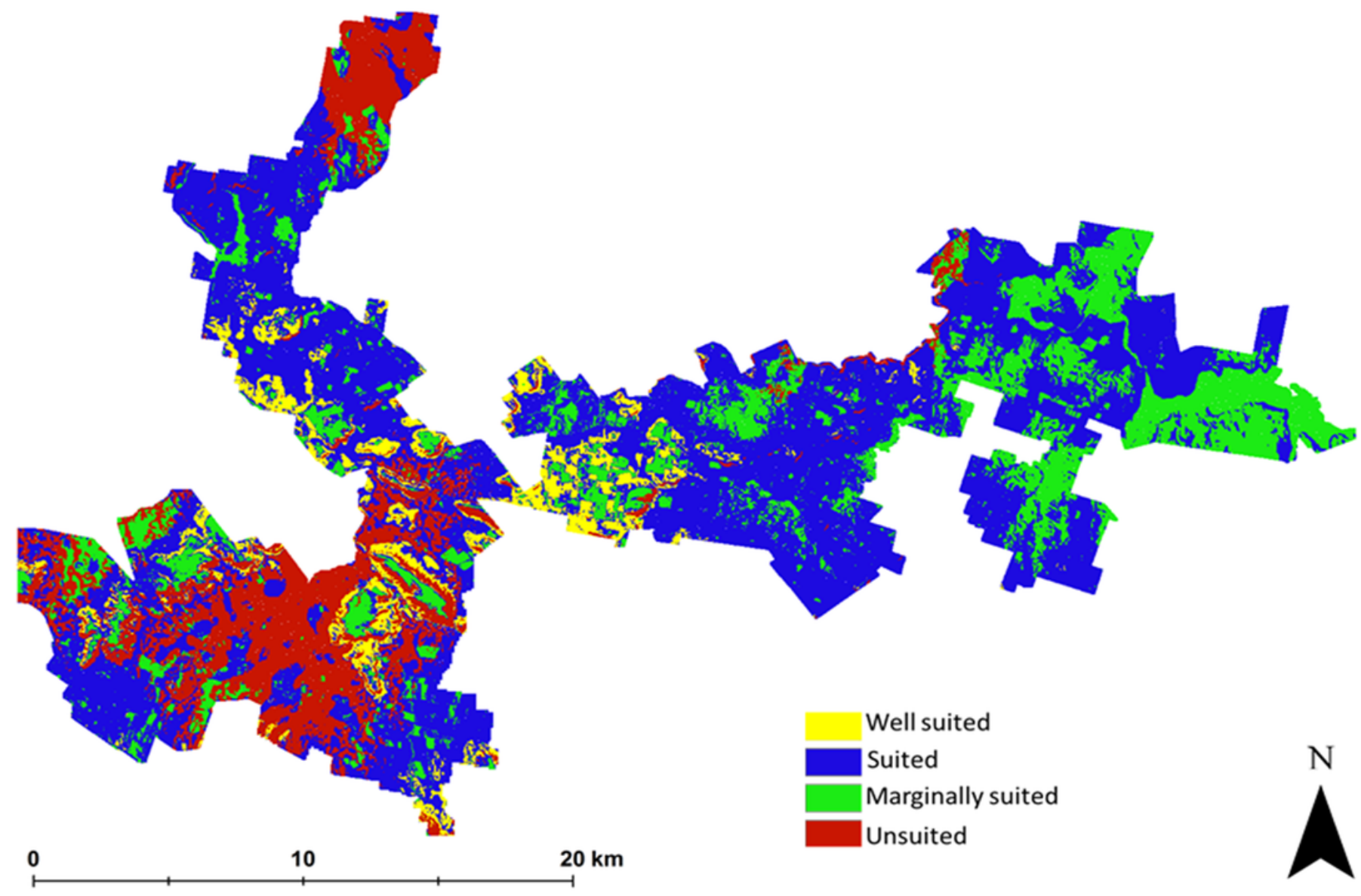


3

Hazelnut suitability class probabilities

Flgure 3. Hazelnut suitability class probabilities a) Well suited, b) suited, c) marginally suited, d) unsuited.
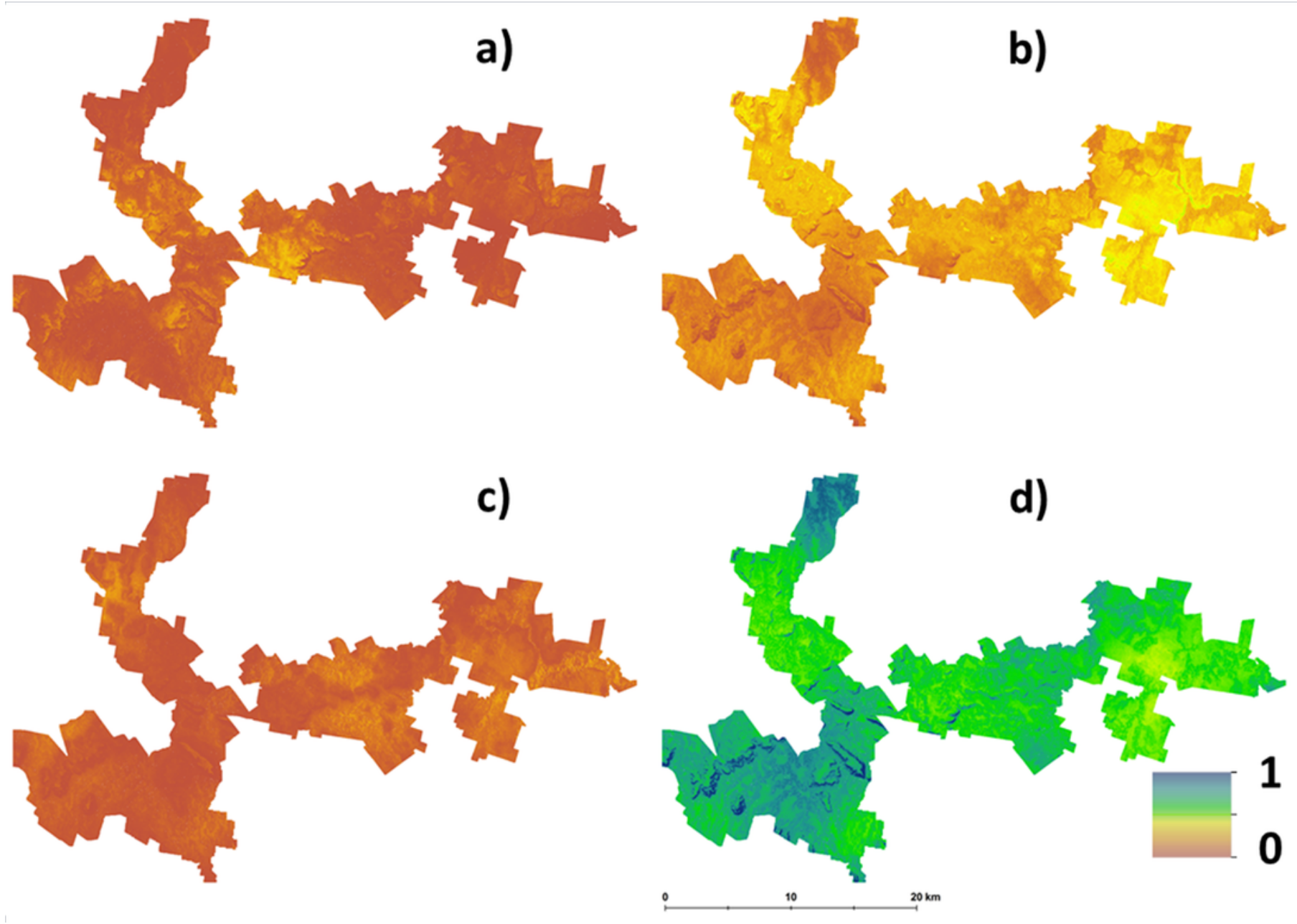


\section{Table $\mathbf{1}$ (on next page)}

Hazelnut suitability parameters

Table 1. Suitability parameters and thresholds for hazelnuts. Sourced from DPIPWE (2015). 


\begin{tabular}{|c|c|c|c|c|c|c|c|c|c|c|}
\hline & \multicolumn{6}{|c|}{ Soil variables } & \multicolumn{4}{|c|}{ Climate variables } \\
\hline $\begin{array}{l}\text { Suitability } \\
\text { class }\end{array}$ & $\begin{array}{c}\text { Soil } \\
\text { depth } \\
\text { (cm) }\end{array}$ & $\begin{array}{c}\text { Soil pH } \\
(1: 5 \\
\text { soil } \\
\text { water }) \\
\text { top } \\
15 \mathrm{~cm} \\
\text { of soil }\end{array}$ & $\begin{array}{c}\text { Soil } \\
\text { conductivity } \\
\text { (dS/m) top } \\
15 \mathrm{~cm} \text { of soil }\end{array}$ & $\begin{array}{c}\text { Soil } \\
\text { texture } \\
(\% \\
\text { clay }) \\
\text { top } \\
15 \mathrm{~cm} \text { of } \\
\text { soil }\end{array}$ & $\begin{array}{c}\text { Soil } \\
\text { Drainage }\end{array}$ & $\begin{array}{c}\text { Stoniness } \\
(>2 \mathrm{~mm}) \\
\text { of the top } \\
15 \mathrm{~cm} \mathrm{of} \\
\text { soil }\end{array}$ & $\begin{array}{c}\text { Incidence of } \\
\text { frost } \\
\text { (Probability } \\
\text { of zero days } \\
\text { in June, } \\
\text { July or } \\
\text { August } \\
\text { where } \\
\text { temperature } \\
\text { reaches - } \\
6^{\circ} \mathrm{C} \text { ) }\end{array}$ & $\begin{array}{c}\text { Mean } \\
\text { maximum } \\
\text { monthly } \\
\text { temperature. } \\
\text { Mean } \\
\text { January or } \\
\text { February } \\
\text { max temp } \\
\left({ }^{\circ} \mathrm{C}\right)\end{array}$ & $\begin{array}{c}\text { Rainfall } \\
\text { (March } \\
\text { mean) }\end{array}$ & $\begin{array}{c}\text { Chill hour } \\
\text { requirements } \\
\text { (Chill hours } \\
\text { 0-7º April- } \\
\text { August } \\
\text { inclusive) }\end{array}$ \\
\hline $\begin{array}{l}\text { Well } \\
\text { Suited }\end{array}$ & $>50 \mathrm{~cm}$ & $5.5-6.5$ & $<0.15$ & $10-30$ & $\begin{array}{c}\text { Well to } \\
\text { moderately } \\
\text { well } \\
\text { drained }\end{array}$ & $<10 \%$ & $>=80 \%$ & $20-30$ & $<50 \mathrm{~mm}$ & $>1200$ \\
\hline Suited & $\begin{array}{c}40-50 \\
\mathrm{~cm}\end{array}$ & & & $30-50$ & $\begin{array}{l}\text { Imperfectly } \\
\text { drained }\end{array}$ & $10-20 \%$ & $60-80 \%$ & $\begin{array}{c}30-33 \text { and } \\
18-20\end{array}$ & & $600-1200$ \\
\hline $\begin{array}{l}\text { Marginally } \\
\text { Suited }\end{array}$ & $\begin{array}{c}30-40 \\
\mathrm{~cm}\end{array}$ & $6.5-7.1$ & & & & & $40-60 \%$ & $33-35$ & & \\
\hline Unsuited & $<30 \mathrm{~cm}$ & $\begin{array}{l}<5.5 \text { or } \\
>7.1\end{array}$ & $>0.15$ & $\begin{array}{l}>50 \text { or } \\
<10\end{array}$ & $\begin{array}{l}\text { Poor to } \\
\text { very poorly } \\
\text { drained }\end{array}$ & $>20 \%$ & $<40 \%$ & $>35$ or $<18$ & $>50 \mathrm{~mm}$ & $<600$ \\
\hline
\end{tabular}




\section{4}

Probabilities of each soil and climate variable causing hazelnuts to be unsuitable for establishment.

Figure 4. Probabilities of each soil and climate variable causing hazelnuts to be unsuitable for establishment, a) chill hours, b) clay content, c) soil drainage, d) soil conductivity, e) frost occurrence, f) soil $\mathrm{pH}, \mathrm{g}$ ) rainfall, h) soil depth, i) temperature, j) rock fragments. 

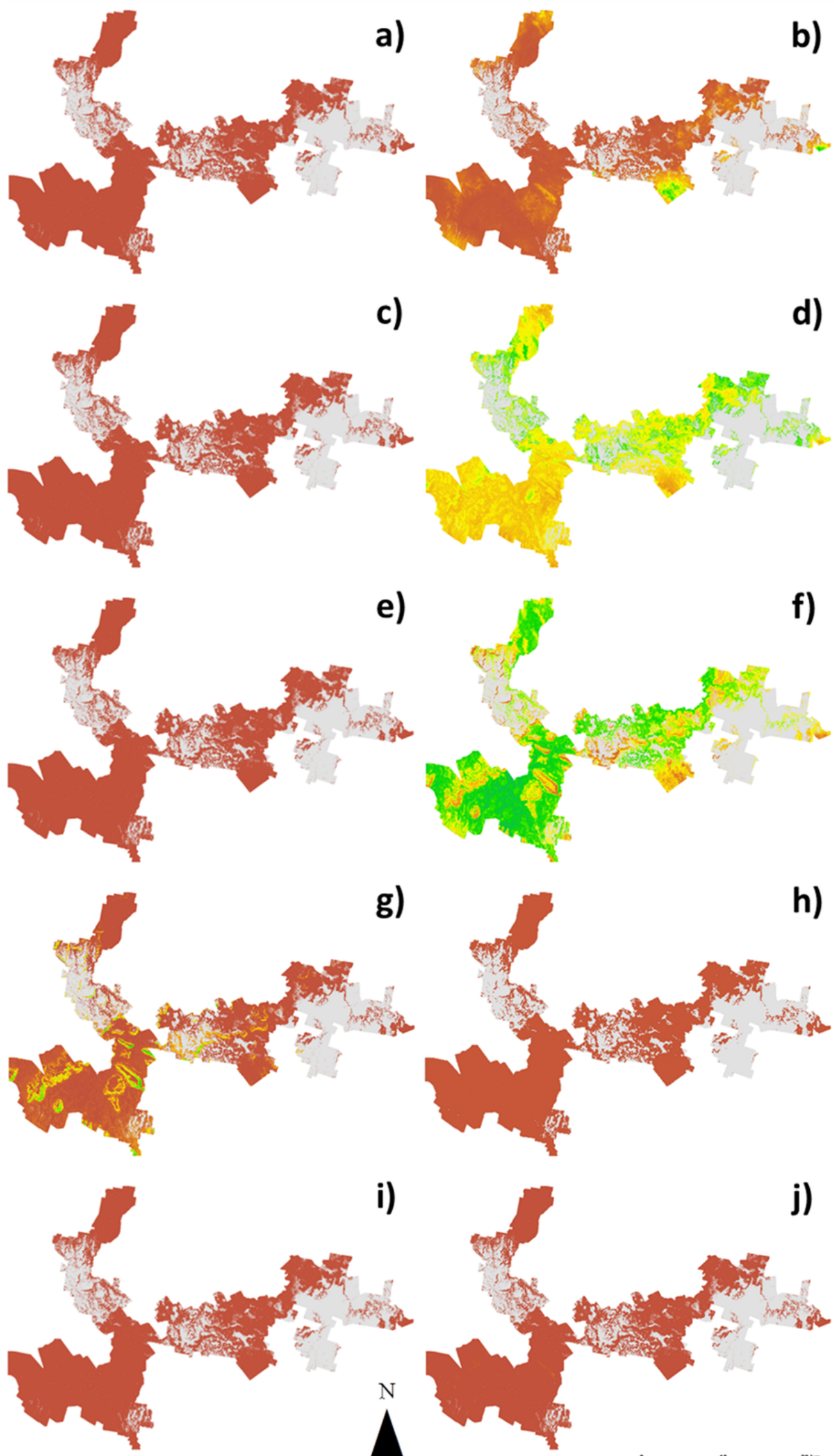

i)
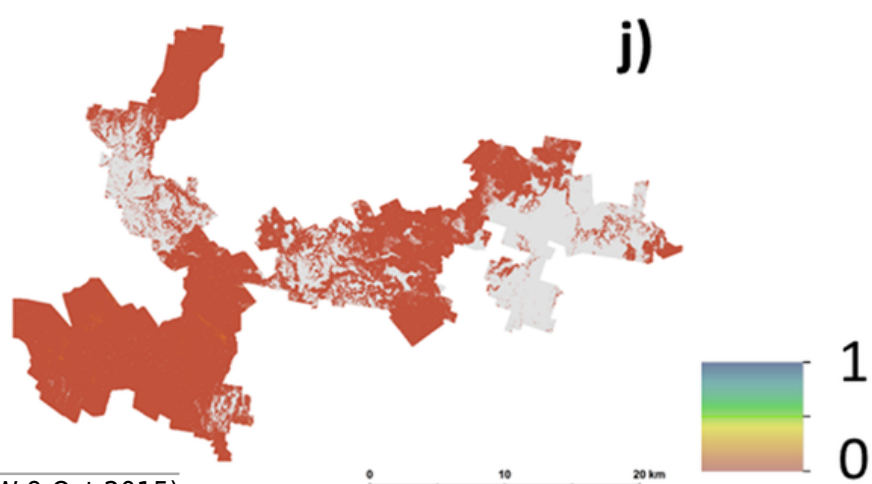


\section{Table 2 (on next page)}

Model diagnostics

Table 2. Metadata and model diagnostics of digital soil and climate mapping relevant to LSA for hazelnuts. 


\begin{tabular}{|c|c|c|c|c|c|}
\hline Variable & $\begin{array}{l}\text { Number of } \\
\text { observations }\end{array}$ & Model used & $\begin{array}{l}\text { Residual } \\
\text { modeling } \\
\text { (variograms) }\end{array}$ & $\begin{array}{l}\text { Validation } \\
\text { statistics }\end{array}$ & PICP \\
\hline \multirow{2}{*}{ Soil depth (cm) } & 1. $432(144)$ & $\begin{array}{l}\text { 1. Binomial } \\
\text { logistic } \\
\text { regression }\end{array}$ & \multirow{2}{*}{ 2. Yes } & $\begin{array}{l}\text { 1. } \mathrm{OA}=87 \% \\
\text { Kappa }=0\end{array}$ & \multirow{2}{*}{$\begin{array}{l}2 . \\
92 \%\end{array}$} \\
\hline & 2. $56(20)$ & $\begin{array}{l}\text { 2. Cubist model } \\
\text { regression } \\
\text { kriging ( } 1 \text { rule) }\end{array}$ & & $\begin{array}{l}\text { 2. } \mathrm{RMSE}=16.2 \\
\mathrm{CCC}=0.31\end{array}$ & \\
\hline $\begin{array}{l}\text { Soil pH (1:5 soil water) top } \\
15 \mathrm{~cm} \text { of soil }\end{array}$ & $432(144)$ & $\begin{array}{l}\text { Cubist model } \\
\text { regression } \\
\text { kriging ( } 1 \text { rule) }\end{array}$ & Yes & $\begin{array}{l}\mathrm{RMSE}=0.44 \\
\mathrm{CCC}=0.25\end{array}$ & $92 \%$ \\
\hline $\begin{array}{l}\text { Soil conductivity }(\mathrm{dS} / \mathrm{m}) \text { top } \\
15 \mathrm{~cm} \text { of soil }\end{array}$ & $426(143)$ & $\begin{array}{l}\text { Cubist model } \\
\text { regression } \\
\text { kriging ( } 1 \text { rule) }\end{array}$ & Yes & $\begin{array}{l}\mathrm{RMSE}=0.12 \\
\mathrm{CCC}=0.09\end{array}$ & $81 \%$ \\
\hline $\begin{array}{l}\text { Soil texture (\% clay) top } \\
15 \mathrm{~cm} \text { of soil }\end{array}$ & $269(94)$ & $\begin{array}{l}\text { Cubist model } \\
\text { regression } \\
\text { kriging ( } 1 \text { rule })\end{array}$ & Yes & $\begin{array}{l}\mathrm{RMSE}=7.77 \\
\mathrm{CCC}=0.38\end{array}$ & $90 \%$ \\
\hline Soil Drainage & $431(144)$ & $\begin{array}{l}\text { Cubist model } \\
\text { regression } \\
\text { kriging ( } 1 \text { rule) }\end{array}$ & Yes & $\begin{array}{l}\mathrm{RMSE}=0.70 \\
\mathrm{CCC}=0.52\end{array}$ & $91 \%$ \\
\hline \multirow{2}{*}{$\begin{array}{l}\text { Stoniness class }(>200 \mathrm{~mm}) \text { of } \\
\text { the top } 15 \mathrm{~cm} \text { of soil }\end{array}$} & 1. $432(144)$ & $\begin{array}{l}\text { 1. Binomial } \\
\text { logistic } \\
\text { regression }\end{array}$ & & $\begin{array}{l}\text { 1. } \mathrm{OA}=85 \% \\
\text { Kappa }=0.15\end{array}$ & \\
\hline & 2. $46(18)$ & $\begin{array}{l}\text { 2. Ordinal } \\
\text { logistic } \\
\text { regression }\end{array}$ & & $\begin{array}{l}\text { 2. } \mathrm{OA}=34 \\
\text { Kappa }=0\end{array}$ & \\
\hline \multirow{2}{*}{$\begin{array}{l}\text { Incidence of frost } \\
\text { (Probability of zero days in } \\
\text { June, July or August where } \\
\text { temperature reaches }-6^{\circ} \mathrm{C}\end{array}$} & 1. $129(44)$ & $\begin{array}{l}\text { 1. Binomial } \\
\text { logistic } \\
\text { regression }\end{array}$ & \multirow{2}{*}{ 2. No } & $\begin{array}{l}\text { 1. } \mathrm{OA}=91 \% \\
\text { Kappa }=0.30\end{array}$ & \multirow{2}{*}{$\begin{array}{l}2 . \\
60 \%\end{array}$} \\
\hline & 2. $14(5)$ & $\begin{array}{l}\text { 2. Multiple linear } \\
\text { regression model }\end{array}$ & & $\begin{array}{l}\text { 2. } \mathrm{RMSE}=25 \\
\mathrm{CCC}=0\end{array}$ & \\
\hline $\begin{array}{l}\text { Mean maximum monthly } \\
\text { temperature. Mean January } \\
\text { or February max temp }\left({ }^{\circ} \mathrm{C}\right)\end{array}$ & $129(44)$ & $\begin{array}{l}\text { Cubist regression } \\
\text { model (1 Rule) }\end{array}$ & No & $\begin{array}{l}\mathrm{RMSE}=0.60 \\
\mathrm{CCC}=0.62\end{array}$ & $88 \%$ \\
\hline Rainfall (March mean) & 21 & $\begin{array}{l}\text { Multiple linear } \\
\text { regression }\end{array}$ & No & $\begin{array}{l}\mathrm{RMSE}=3.23 \\
\mathrm{CCC}=0.69\end{array}$ & $90 \%$ \\
\hline $\begin{array}{l}\text { Chill hour requirements } \\
\text { (Chill hours } 0-7^{\circ} \mathrm{C} \text { April- } \\
\text { August inclusive) }\end{array}$ & $129(44)$ & $\begin{array}{l}\text { Cubist regression } \\
\text { model (2 Rules) }\end{array}$ & Yes & $\begin{array}{l}\mathrm{RMSE}=54 \\
\mathrm{CCC}=0.84\end{array}$ & $82 \%$ \\
\hline
\end{tabular}




\section{5}

Contribution of soil conductivity and pH to assessment of unsuitability for hazelnuts.

Figure 5. Contribution of soil conductivity and $\mathrm{pH}$ to assessment of unsuitability for hazelnuts

a) and b) assuming inputs are error free, c) and d) taking account of the associated prediction uncertainties.
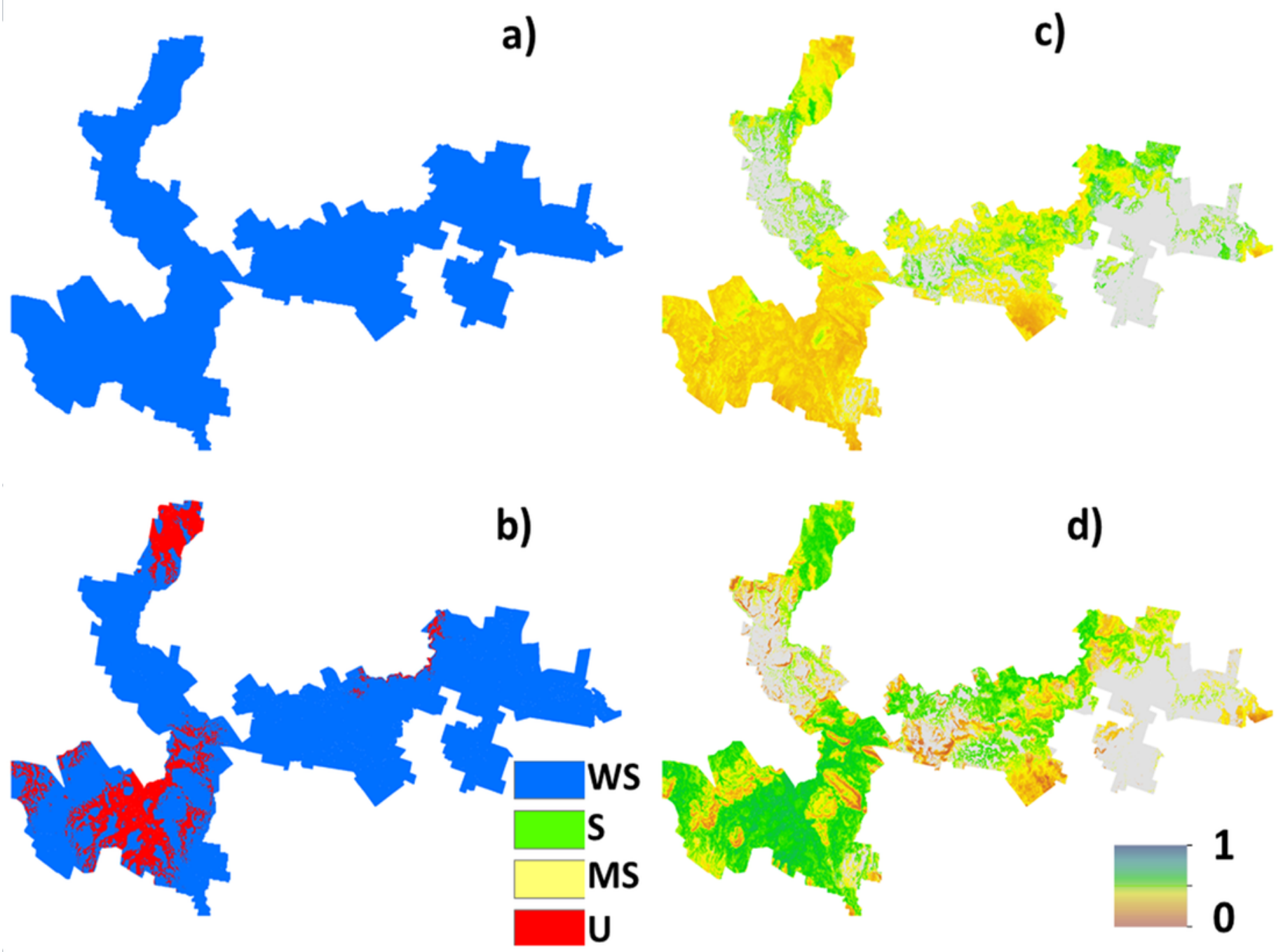
6

Probability of multiple factors

Figure 6. Probability of multiple factors that contribute towards unsuitability for hazelnut establishment.

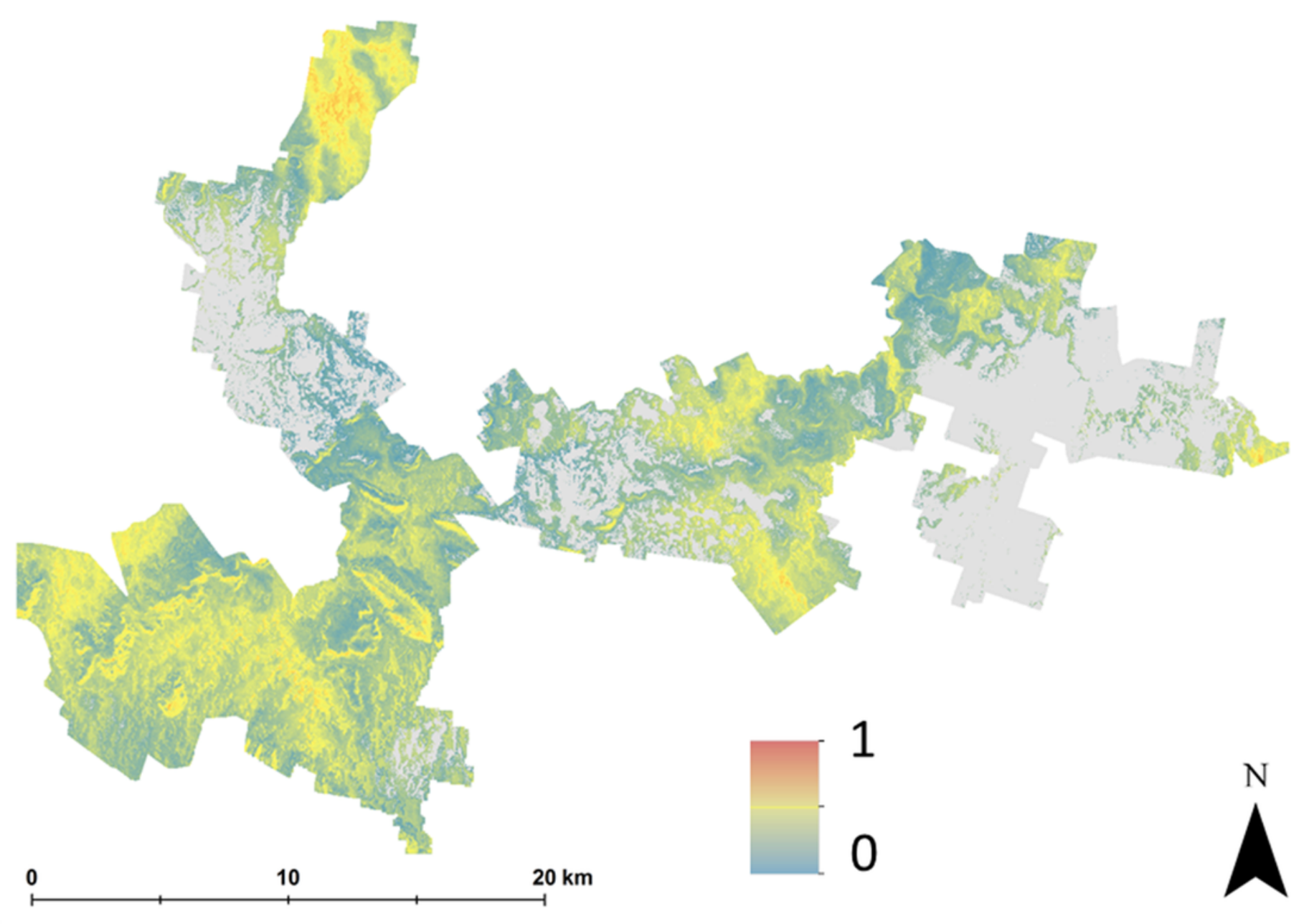

